\title{
No culture shock? Addressing the Achilles heel of modern Bible translations
}

S J Joubert

(University of Pretoria)

\section{ABSTRACT}

No culture shock? Addressing the Achilles heel of modern Bible translations

Modern Bible translations are often more sensitive to the needs of their intended readers than to the right of biblical texts to be heard on their own terms as religious artefacts from the ancient Mediterranean world. Since all biblical documents linguistically embody socio-religious meanings derived from ancient Mediterranean societies, they also need to be experienced as different, even alien, by modern readers. Without an initial culture shock in encountering a Bible translation modern people are held prisoners by Western translations of the Bible. Therefore, translations should instil a new sensitivity among modern readers to the socio-cultural distance between them and the original contexts of the Bible. In order to help facilitate this historical awareness, a new generation of "value added" translations must, in creative and responsible ways, begin to provide a minimum amount of cultural information to assist modern readers in assigning legitimate meanings to the linguistic signs encapsulated on the pages of the Bible.

\section{INTRODUCTION}

The translation of the Bible is a contentious and sensitive issue. As the basis text of Christianity, the Bible embodies, symbolises and communicates the noblest values, ideals and hopes of believers throughout the ages. The Bible is the gateway to faith - it is considered by millions of believers worldwide as a direct window to God's heart! Therefore any translation of the Bible touches the religious nerve system of the communities for whom it is intended.

Traditionally, Bible translations tend to be rather conservative. Major translations, such as the King James Version, the American Standard Version and the 1953 Afrikaans Bible Translation follow the syntactic and lexical meanings expressed in the source languages as closely as possible. By translating every word from the original Greek or Hebrew into an exact equivalent in the receptor language, translators within this theoretical paradigm aim to faithfully preserve the "true meaning" of Scripture. Over against this dynamic-equivalent approach to 
Bible translation, a second theoretical angle of incidence became dominant in the second half of the twentieth century, the so-called dynamic equivalent approach. Adherents of this approach, whose views found expression in translations such as the New International Version and the New Revised Standard Version, consider a good translation one where the connotations, rhetorical impact and emotive meaning of the original text are reflected to the best degree possible, without necessarily following the word arrangement and grammar characteristic of the original language.

The aim of this paper is to briefly evaluate some of the strengths and weaknesses of modern Bible translations and to offer indicators for the way forward. Firstly, a brief overview of translation philosophy/ies and methodology/ies of major modern translations is presented, before a few pitfalls in this regard are identified. Finally, guidelines for an approach to Bible translation, which is sensitive to the social location of the translator as well as to the cultural context of the original authors and audiences of the respective biblical documents, will be put on the table.

\section{COMING TO TERMS WITH THE "DYNAMICS" OF MO- DERN TRANSLATIONS}

\subsection{Philosophy/ies and methodology/ies}

The aim of dynamic-equivalence translations is to have the same impact on a modern audience as the original text had on its audience. Instead of translating every word of the biblical text into an exact equivalent in the receptor language, translators, who basically adhere to the principles of dynamic-equivalence, aim to produce the closest equivalents - in terms of style and understanding - of the meanings encoded in the original language structures. However, on a lower level of abstraction this ideal is applied and expressed differently in modern translations. For instance, the translators of God's Word (1995), who opted for a "closest natural equivalent" translation (cf 1995: xi-xiv), aim firstly to find suitable English equivalents that give expression to the meanings embedded in the original text. Secondly, "readability" is a prerequisite. Therefore, English punctuation is used and, wherever possible, gender-neutral language so that the intended readers will be able to apply relevant biblical passages to their own modern contexts. Thirdly, the translators of God's Word chose the natural equivalent terms/expressions/phrases that mostly reflect the style of the Hebrew, Aramaic, or Greek texts. Over against the awkwardness and inaccuracy often associated with form-equivalent translations, which closely follow the word arrangement and structure of the original language, the translators of God's Word try to address the loss of meaning by, amongst others, avoiding long, complicated sentences, varying the word arrangement and substituting theological concepts 
with terms that can be understood easily by readers with no theological training.

The translating committee of the New Living Translation (NLT) opted for a "thought for thought translation". Their methodology (see Introduction to the Translation) involves an accurate interpretation of the original, and secondly the rendering of the text in understandable idiom in the receptor language. Exegetical reliability and idiomatic readability are thus their basic aims. To achieve the first aim, the translators believe that the application of what they term "the best" exegetical tools, as well as a thorough understanding of the thought-patterns of the ancient authors, will produce the necessary results. In order to achieve the aim of readability, the committee, in the foreword to the $N L T$, explicitly addresses a number of hermeneutic issues, such as the translation of ancient weights, measures, currency values, calendars, and time indications. In this regard they opt for recognisable contemporary equivalents. When dealing with words and phrases that "carry a great deal of cultural meaning", or metaphoric language, the translators opt for the principle of clarity by expanding literal phrases that are difficult to understand, or by turning metaphors into similes. Poetry in the original language is also turned into prose for the sake of easier reading.

From these examples it is clear that so-called dynamic-equivalent translations concentrate on the exegetical meaning of the original text, as well as on the question, how this meaning may be expressed best in the target language. Recent developments within the fields of linguistics and semantics obviously encouraged Bible translators to hold a much broader understanding of the concept "meaning". Over against traditional views, which hold that meaning is embedded in specific words, and may be transported to and expressed in similar words in other languages, most modern translators determine meaning in terms of the total expression of utterances, including the syntax of how words, phrases, and paragraphs are interconnected. According to Wayne Lehman (Internet), aspects such as the denotation of words, the implicit meanings attached to concepts in specific cultures, the rhetorical impact of verbal utterances and stylistic features must be taken into consideration when meaning is at stake. In his own words:

"A good translation will reflect, to the best degree possible, the connotations, rhetorical impact, and the emotive style of the original text. Total accuracy requires preserving all of these aspects of the original meaning, lexical meaning, syntactic and discourse meaning, implicit meaning (that which is necessary for accurately understanding an utterance), connotations, rhetorical impact, and other aspects of good style". 
At the same time, clarity of expression and naturalness of language is of great importance. Not surprisingly, most modern versions of the Bible share the presupposition that a translation should not sound like one; the Bible must be translated into the intended readers' normal vocabulary.

The modern era of the reader-friendly Bible, which communicates effectively and smoothly in the idiom of modern readers, is somewhat different from the heyday of the literal translation, with its rather clumsy grammatical structures and unintelligible phrases. However, this very fact, as well as the sensitivity of translators to "contemporary" ideological issues such as political correctness, the use of gender neutral language, the rearrangement of Biblical discourses along the lines of modern patterns of argumentation, etc, have turned many of today's editions of the Bible into completely new, Western texts, where modern cultural artefacts, ideologies and meanings are all too easily imposed on these ancient religious documents.

\subsection{A further development: "value added" translations}

In recent years the international Bible arena also experienced the introduction of so-called "value added" versions of existing translations, which incorporate various hermeneutic tools to more effectively facilitate modern readers in the interpretative process. This "enrichment" includes the indication of alternative translation possibilities; the use of grammatical explanations and lexical aids (cf The Hebrew-Greek Key Word Study Bible, based on the New International Version translation); the addition of footnotes, extensive introductions to Bible books, cross references, and the highlighting of biblical promises (cf the Touch Point Bible, based on the NLT); etc. Audio-visual versions and age group focussed editions of popular translations have also become readily available worldwide. The Teen Study Bible and The New Adventure Bible, both based on the text of the NIV, are two examples of "hermeneutic value added" translations primarily directed at the teenager market. The abundant use of neon colours, diagrams, pictures, short Bible studies, and background information, typify these editions.

The publication of simplified versions of biblical material for children is a further development related to the field of Bible translation. Children's' Bibles are not novel. But where the traditional Children's Bible was based on a selected, visual-narrative version of biblical material, the emphasis has shifted to the publication of more comprehensive versions of the biblical text (cf God's Story. The Bible told as one story), to complete translations intended principally for children (Die Nuwe Testament vir Kinders). 
It appears as if the production of new translations of the Bible in the international arena is progressively making way for the enrichment of existing, successful translations, which are directed at diverse markets. Modern people's incessant need for visual stimulation and alternative, new mediums of communication, but also modern readers' increasing inability to comprehend the nature and contents of the Bible, provide the ideal platform for these "value added" editions. It seems that the days are counted that Bible translators can leave translations without trepidation in the hands of knowledgeable readers. It cannot be taken for granted any longer that modern readers have the required skills to accomplish legitimate interpretations of biblical material. According to proponents of these value added editions, additional tools are required to assist modern readers actively and effectively in the understanding process.

\section{WHY NO CULTURE SHOCK?}

Significant developments within the theory and practice of translation have completely and permanently altered the landscape of modern Bible translation - undoubtedly for the better. However, modern translation theories still suffer from the lack of a comprehensive engagement with the cultural meanings encoded in the original biblical documents. Put differently, the Achilles heel of modern translations seems to be the fact that they have not yet fully come to terms with the formative impact of ancient Mediterranean cultural contexts on the meanings expressed in the language structures of the biblical documents.

The noble aim of translators of the Bible to communicate effectively in the language of receptor cultures has, unfortunately, turned many modern editions into totally Western texts that fit in contemporary contexts far too snugly. Therefore, modern "consumers of the Bible" are not always assisted in these user-friendly editions to come to terms with the socio-cultural distance between the Bible and present contexts. Perhaps this is due to the fact that translators themselves often employ hermeneutic and exegetical tools primarily developed for the interpretation of modern forms of discourse. As a result, the inherent strangeness of the biblical text, which originated in a totally different cultural world from ours, is not accounted for sufficiently within the majority of modern translations.

New worlds were opened for Bible translators by the remarkable insights of scholars such as Barr, Nida and Louw. As a consequence of their ground breaking work, the belief that words between languages completely cover each other is now outdated, as is the belief that a root meaning in individual words can be determined through various etymological inquiries. Translators are now able to come to terms with the semantic fields of biblical words and concepts more effectively through sophisticated lexicons (see Louw \& Nida 1988). However, the analysis 
of the various cultural frameworks in which the biblical texts originated is still reduced to mere background information. In other words, sociohistorical information is seen as only one of the prerequisites to the actual interpretive process, one of many facets, which translators must take into consideration when they are trying to unlock the meaning of biblical texts (see, e g, the introduction to both the Revised NIV [1983] and the $N L T[1996])$.

Admittedly, the so-called value added translations make an asserted effort to sensitise modern readers to the different nature of the original biblical world(s). For instance, The New Adventure Bible (The NIV Study Bible for Kids) provides the youth with background information on the origins of different Bible books, along with useful maps and short explanations of important theological and historical considerations. Spiros Zodhiates, editor of the Hebrew-Greek Key Study Bible, mentions in his foreword that this edition aims to provide the modern Bible reader with a "complete study tool" through its attempt to unlock the essential aspects of the original biblical languages' syntax and vocabulary. But, at best, these aspects only serve as additional tools to facilitate the understanding of inherently "westernised" translations.

\section{A BROADENED HERMENEUTIC APPROACH: MEANING AS SOCIAL CONSTRUCT}

Meaning always functions within the parameters of a social system (Malina 2001b:152). Any cultural system endows objects, persons and events with specific, shared meanings, values and feelings (Malina 2001a:9). Language, in turn, serves as an important storehouse and communicative vehicle of these socially shared meanings. To approach the interpretation of biblical meaning only in terms of the study of the different semantic relations between words and phrases, without a proper theoretical framework that deals with the nature of the cultural systems within which language structures attained specific meanings, is to open the door to ethnocentric translations of the Bible. In order to prevent this pitfall, the social location of the modern translator, as well as the various social contexts within which the biblical texts originally communicated ( $\mathrm{cf} \mathrm{De}$ Silva 2000:17-18; Elliott 2001:8), must be taken into consideration during all phases of the translation process.

The ancient Mediterranean culture, within which biblical documents were produced, infused the written signs on the pages of the original biblical texts with culturally-specific meanings and patterned them in socially appreciable ways for their intended readers, definitely not for modern, third millennium, consumers of the Bible. Therefore, explicit explanatory frameworks that operate on various levels of abstraction should be used as "foreground information" in order to ensure the correct translation of the linguistic signs that we encounter in the Bible. 
Without such heuristic guides, we cannot fully understand or appreciate fully what the ancients meant in their religious documents, let alone translate them correctly into modern contexts. Formal knowledge of ancient Hebrew or Greek grammar is not sufficient. This type of knowledge must be informed by explanatory models to facilitate more precise understandings of the social frameworks of meaning underlying the ancients' behaviour and their various modes of speech. As foreign eavesdroppers in the world of the Bible, an awareness of the specific contents of the cultural cores within the ancient Mediterranean world and the various faith communities addressed in the Bible, should prevent us from superimposing our modern, socially shared ideas and behavioural patterns onto their worlds.

Within the ancient eastern Mediterranean context, kinship formed the focal and overwhelmingly dominant social institution.' The other major social institution was politics, with religion and economics being embedded either in the domestic system or in the political system. Thus, religion was not a freestanding, independent social institution as is the case in most modern societies in our day. It manifested either in the domus or oikos (early Christian groups), or in the political arena (the various temple cults in service of the political elite). At the same time, the foundational value complex of ancient Mediterranean people was oriented around honour/shame, marked off by various boundaries consisting of gender status, authority and social position.

The ancient Mediterranean world was predominantly agrarian, with an average life expectancy of between 16-20 at birth. Public life and its institutions were dominated by males who constantly competed for honour in agonistic interactions with same-status males outside their families. While males occupied all public spaces, females, who were always considered inferior to males, occupied the private spaces of home and hearth. Ancient Mediterraneans were always non-individualistic and strongly group-oriented. In other words, they had a collective self-awareness, with being as their principal mode of existence over doing. Instead of conceiving, implementing and fulfilling personal (= individualistic) goals, persons within Mediterranean societies were socialised into constantly focusing on their group's goals and priorities and living up to these stereotyped expectations. Due to the fact that the ancients' identi-

${ }^{1}$ Constant awareness of the specific ways in which the ancients gave verbal expression to significant value objects, such as themselves, others, time and nature, could provide appropriate lenses for modern interpreters with which to analyse and translate the Bible. Following the work of cultural anthropologists and biblical scholars such as Gillmore (1982), Hanson \& Oakman (1998), DeSilva (2000), Pilch (2000) and Malina (2001b), a basic construct, on a high level of abstraction, of the world in which the biblical documents originated is offered here to underscore its uniqueness. 
ties were directly related to their social embeddedness in their respective groups ("son of X; member of party Y; citizen of Z"), collateral and hierarchical relationships were of crucial importance to them. In other words, being dyadic personalities, they continually needed reinforcement from others around them in various hierarchical positions on the social ladder to know who they really were. At the same time, their time orientation moved from present to past, not from present to future, as is the case in most modern contexts. They also viewed themselves as being subject to nature, never its masters. Thus, in terms of nature as a major value object, ancient Mediterraneans constantly strived to live in harmony with it. Since they viewed nature as a divine force, infused with all kinds of deities, supernatural powers and demons, they were never interested in subjecting it.

\section{DIFFERENT FRAMEWORKS OF UNDERSTANDING, DIF- FERENT TRANSLATIONS}

If it is considered a prerequisite for translators, exegetes and theologians to understand biblical texts against the backdrop of the cultural contexts in which they were originally produced, the question needs to be raised again why readers often experience no "culture shock" when they read modern translations of the Bible? Is it perhaps not possible that many of today's popular Bible translations have turned into ethnocentric or anachronistic religious documents, which, if I may use Murray Krieger's well-known typology, now only serve as mirrors for modern people to view themselves and not also as windows into the worlds of the original authors and readers? In view of recent developments within the field of the social-scientific analysis of the Bible, it is untenable to view the study of historical and social data reflected in the biblical documents merely as a vantage point, as one of the many phases leading up the actual exegetical and translation process.

Let us consider sickness in the healing stories in the Gospels to explain the necessity of "culturally accurate" translations. In most modern editions of the Bible, terms such as iáoual or iatpós are translated along the lines of Western biomedical interpretations of sickness. For example, both the $N L T$ and $N I V$ translate the term iatpós in Matthew 9:12 as "doctor," or a $\sigma \theta \in \nu \in \omega_{\omega}$ in Luke $4: 40$ with disease or sickness, which is culturally incorrect. Had the translators paid closer attention to the nature of the Mediterranean culture from which Matthew derived his meanings, they would have noticed that the term sickness is not actually a blanket term for illness/disease, but "a process for socializing disease and illness" (Young 1982:70). Medical anthropologists, such as Young (1982) and Kleinman (1980), and more recently, the biblical scholar, John Pilch (2000), have shown that the concept "disease", as an explanatory concept of the reality "sickness," relates to the distinctive Western 
perspective to the management of sickness, whereby a medical practitioner or therapist focuses on curing biomedical and psychological disorders to bring about a cure. They then intervene to eradicate the internal disease, that is, to bring about a cure. From a Mediterranean cultural perspective, however, the "healing activities" of Jesus and other healers should be understood in terms of "illnesses" which are not simply biological realities. Jesus and other professional and folk healers were clearly not doctors licensed to specialise in healing activities in the modern sense of the word (as might be implied in the translation of the term

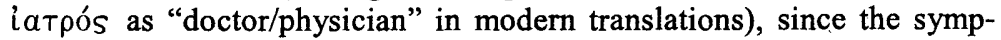
toms and the illness that they dealt with represented personal and group values. Ancient Mediterranean healers followed different healing strategies in different social contexts, which were never constrained by biomedical principles. Since illness was, for them, always concerned with the socio-cultural meaning of any sickness experience, there was usually a disregard for biomedical symptoms (which is essential to the curing of modern disease).

In Jesus' healings, there is constant concern for social and personal meaning, which is typical of the cultural understanding of illness. Apart from the fact that many of his healings took place in synagogues within the framework of his teaching ministry, he frequently changed the status of the affected persons in their communities in terms of clean/unclean (Lk 17:13). More specifically, Jesus affected the experiences of the sick by forgiving their sins, thus restoring their relationship with God, and by returning them to their families. Following the taxonomy of illness in the Gospels, it is also clear that Jesus dealt with illness on a metaphysical (in terms of supernatural causes) and habitual (no supernatural entity involved) level. By reformulating the petitioners' self-understanding - "from clean to clean, from undeserving of compassion to finding mercy" (Pilch 2000:53), he provided ultimate meaning for illness.

Most modern translations understand the condition translated as leprosy (cf, eg, the NIV and NLT translations of Lk 17:11-19) in terms of a modern, biomedical perspective. The footnote added to verse 12 by the editors of the NIV Teen Study Bible that the Greek word for leprosy was used for various diseases (sic!) affecting the skin- not necessarily leprosy, underscores this fact. Many translators, who live in societies in which Western biomedical views of sickness dominate uncritically, share the cultural bias that all forms of illness reported in the Bible must have been symptomatic of some underlying biological disorder in individual patients. Therefore, translators, following numerous modern biblical scholars and physicians, often try to "decode" certain forms of illness in the Bible, such as "leprosy" by relating it to known diseases in Western medicine, such as psoriasis, seborrhoeic dermatitits, etc. In a recent monograph, Wilkinson (1998), who goes to great lengths to link biblical 
illnesses to various modern biomedical conditions (1998:42ff; 70ff), states that leprosy is actually "a generic term covering a whole group of skin diseases which share some common abnormal features" (1998:48). From a cultural perspective, however, the appearance of any physical abnormality on the skin in the biblical world would have immediately caused the person and his/her group to construct a personally and socially meaningful illness out of this reality (see Pilch 2000:46-48). The semantic meaning related to this illness in ancient Mediterranean societies is uncleanness/unholiness, which implied the physical removal of the individual from his/her group. Thus, the meaning of this condition was related to a process of social ostracising; it implied a life doomed to social rejection and a loss of honour. Small wonder then, that in most instances these unclean people asked Jesus to make them clean (Mk 1:40-45; Lk 5:12-15), or to have compassion for them ( $\operatorname{Lk} 7: 13)$.

Jesus was clearly not a modern physician that intervened to treat his patients' somatic or psychological disorders, but a Mediterranean (folk) healer who treated people's experiences of being socially deprived of compassion due to their uncleanness. By touching them and cleaning them, he frequently established a new meaningful context that reformulated the petitioners' self-understanding from clean to unclean. Clearly, the main aim of Jesus was to address people's socially disvalued states that hindered them to function usefully in society and in the presence of God.

In view of the remarks above, it would be incorrect, in terms of recent research in the field of medical anthropology and biblical studies, to use terms such as illness, disease, healing, curing, doctors, etcetera, indiscriminately as synonyms in modern Bible translations. These terms relate to different understandings of sickness, either in terms of the curing of individual biomedical symptoms, or in terms of the "provision of personal and social meaning for the life problems that accompany human health misfortunes" (Pilch 2000:93).

\section{CONCLUSION: THE CHALLENGE}

One of the major challenges facing modern translators is to come to terms with the frameworks of meaning within which social phenomena such as healing originally took place, so as to produce "culturally correct translations" - even if this implies that modern readers of the Bible could (must!) at times experience an "alienation" effect. The other side of the coin (= the status quo!) is that modern translations will continue to play a major part in keeping anachronistic views of Jesus alive as the divine prototype of modern medical practitioners who cured individuals' biomedical and psychological problems. It will not suffice any longer to pass the buck to exegetes or other interpreters of the Bible to explain the meaning of these concepts in lectures, sermons, etcetera. Without turning 
translations into commentaries, modern editions of the Bible should provide a minimum amount of cultural data to enable modern readers to experience biblical communication in similar manners as the original readers did. Thus, culturally distinctive aspects of ancient Mediterranean societies could be unlocked and communicated in creative, new ways by way of brief reading scenarios. Longer explanatory remarks in the texts could also be used to convey the cultural meaning of specific Greek utterances to modern readers, even if this implies lengthier editions, which include the liberal use of hermeneutical tools, possibly a standard feature of all future Bible translations.

Take once more the illness known in the Bible as leprosy: modern readers, socialised in terms of Western, biomedical interpretations of sickness, need to be sensitised to the fact that ancients who experienced this affliction did not understand it in terms of germs and contagion, but in terms of social pollution. Even though all polluted persons might not even have displayed the same symptoms associated with an illness such as this, once the leaders in their groups deemed them as lepers, personal contact with them immediately polluted others, rendering them impure and unclean. This type of knowledge is essential to guide modern Bible readers to make sense of biblical leprosy - already on the basic level of translations. Alas, incorrect footnotes to this effect, such as in the Teen Study Bible, will not suffice. Reading scenarios, which briefly explain the differences between illness and disease, could, however, go a long way in addressing the huge cultural gap between the understanding of sickness in the biblical world and ours.

Numerous other examples could be added to underscore the point that modern Bible translations are often more sensitive to the needs of their intended readers than to the right of biblical texts to be heard on their own terms as religious artefacts from the ancient Mediterranean world. Since biblical documents linguistically embody socio-religious meanings derived from ancient Mediterranean societies, they need to be experienced as different, even alien, by modern readers. All interpretations that human beings give to their experiences are shaped by their societal systems. Therefore, modern translations should address these strange sounds emanating from the original cultural packaging by providing relevant information to assist modern readers in assigning legitimate meanings to the various linguistic signs encapsulated on the pages of the Bible. Without the initial culture shock in encountering a Bible translation we are held prisoners by Western translations of the Bible. This problem needs to be addressed urgently.

\section{Consulted literature}

De Silva, D 2000. Honor, patronage, Kinship \& purity. Unlocking New Testament culture. Downers Grove: InterVarsity Press. 
Elliott, J H 2001. On wooing crocodiles for fun and profit: Confessions of an intact admirer, in Pilch, J J (ed), Social scientific models for interpreting the Bible. Essays by the Context Group in honor of Bruce J. Malina, 5-20. Leiden: Brill.

Gillmore, D D 1982. Anthropology of the Mediterranean arena. Annual Review of Anthropology 11, 175-205.

Hanson, K C \& Oakman, D E 1998. Palestine in the time of Jesus. Social structures and social conflicts. Minneapolis: Fortress.

Kleinman, A M 1980. Patients and healers in the context of culture. Berkeley: University of California Press.

Lehman, W. Internet: http://www.geocites.com/bible_translation/maxims.htm.

Louw, J P \& Nida, E. 1988. Greek-English Lexicon. Volume 1. New York: UBS.

Malina, B J 2001 a. The New Testament world. Insights from cultural anthropology. 3rd. Ed. Louisville: Westminster John Knox.

Malina, B J 2001b. The social gospel of Jesus. The kingdom of God in Mediterranean perspective. Minneapolis: Fortress.

Peristiany, J G 1966 (ed). Honour and shame. The values of Mediterranean society. Chicago: University of Chicago Press.

Pilch, J J 2000. Healing in the New Testament. Insights from medical and Mediterranean anthropology. Minneapolis: Fortress.

Wilkinson, J 1998. The Bible and healing. A medical and theological commentary. Grand Rapids: Eerdmans.

Young, A 1982. The anthropology of illness and sickness. Annual Review of Anthropology 11, 257-285.

\section{Bible translations}

Die Nuwe Testament vir Kinders. 1999. Carpe Diem: Vanderbijlpark.

Die Radikale Jeugboodskap. 2000. Vereeniging: CUM.

God's Message for Children. 1999. Vereeniging: CUM.

God's Story. The Bible told as one story. 1998. Wheaton: Tyndale.

God's Word. Today's Bible translation that says what it means. 1995. Grand Rapids: World Publishing.

Hebrew-Greek key Word Study Bible (NIV). 1996. Chattanooga: AMG Publishers.

Holy Bible. Living Water (NLT). 2000. Wheaton: Tyndale.

The Message. 1993. Colorado Springs: Navpress.

The New Adventure Bible. The NIV Study Bible for Kids. 1994. Grand Rapids: Zondervan.

The Teen Study Bible (NIV). 1993. Grand Rapids: Zondervan.

Touch Point Bible. God's Word at your point of need (NLT). 1996. Wheaton: Tyndale. 